\title{
HUBUNGAN DUKUNGAN SOSIAL DENGAN MOTIVASI BERPRESTASI PADA MAHASISWA ANGKATAN 2013 FAKULTAS KEDOKTERAN UNIVERSITAS SAM RATULANGI
}

\author{
${ }^{1}$ Wastie R. B. Toding \\ ${ }^{2}$ Lydia David \\ ${ }^{2}$ Cicilia Pali \\ ${ }^{1}$ Kandidat Skripsi Fakultas Kedokteran Universitas Sam Ratulangi Manado \\ ${ }^{2}$ Bagian Psikologi FakultasKedokteran UniversitasSamRatulangi Manado \\ Email: ratutoding131@gmail.com
}

\begin{abstract}
Decline in education quality is no longer a new issue, especially in Indonesia, there are some internal and external factors in low of education quality. An example of internal factor is motivation. Achievement motivation is important in education. Social environment can affect achievement motivation. The purpose of this research is to reveal the correlation between social support and achievement motivation. This research uses analytic-descriptive with cross sectional method. Subjects are chosen by simple random sampling technique. 157 subjects of this research are 2013 generation of Faculty of Medicine students. As the result, the value of $p=0,005<\alpha=0,05$ which means that there is a significant positive correlation between social support and achievement motivation. Correlation coefficient value is 0,223 , which means that the result classification is low, higher social support leads to higher achievement motivation and lower social support leads to lower achievement motivation. Conclusion: There is a significant positive correlation between social support and achievement motivation on 2013 generation of Faculty of Medicine students, Sam Ratulangi University.
\end{abstract}

Keywords: Social Support, Achievement Motivation

\begin{abstract}
Abstrak: Menurunnya kualitas pendidikan bukanlah hal yang baru lagi,khususnya bagimasyarakat Indonesia, rendahnya mutu pendidikan berasal dari faktor internal dan faktor eksternal. Faktor internal meliputi motivasi; motivasi yang penting dalam dunia pendidikan adalah motivasi berprestasi. Salah satu hal yang dapat mempengaruhi pembentukan motivasi berprestasi adalah lingkungan sosial. Penelitian ini bertujuan untuk mengetahui hubungan dukungan sosial dengan motivasi berprestasi. Penelitian ini bersifat deskriptif analitik dengan pendekatan cross sectional, teknik pengambilan sampel yang digunakan yaitu simpel random sampling. Subyek penelitian adalah mahasiswa angkatan 2013 Fakultas Kedokteran Universitas Sam Ratulangi dengan jumlah 157 subyek. Teknik analisa data dengan menggunakan uji korelasi Sperman Rank dengan tingkat kemaknaan $\alpha=0,05$. Hasil penelitian didapatkan nilai $\mathrm{p}=0,005<\alpha=0,05$, menunjukkan bahwa terdapat hubungan positif yang signifikan antara dukungan sosial dengan motivasi berprestasi. Nilai koefisien korelasi sebesar 0,223 termasuk kedalam kategori rendah, artinya semakin tinggi dukungan sosial maka semakin tinggi motivasi berprestasi, sebaliknya semakin rendah dukungan sosial maka semakin rendah motivasi berprestasi. Simpulan: Terdapat hubungan positif yang signifikan antara dukungan sosial dengan motivasi berprestasi pada mahasiswa angkatan 2013 Fakultas Kedokteran Universitas Sam Ratulangi.
\end{abstract}

Kata kunci: Dukungan sosial, Motivasi berprestasi 
Menurunnya kualitas pendidikan bukanlah hal yang baru lagi,khususnya bagi masyarakat Indonesia. Hal ini dapat dilihat dari survei yang dilakukan oleh Global Competitiveness Report tahun 2009/2010 yang menilai tingkat persaingan global Indonesia dari kualitas pendidikan menempati peringkat ke-54 dari 133 negara, yaitu dibawah Singapura, Malaysia, Cina,Thailand, serta India.

Salah satu faktor yang mempengaruhi prestasi adalah motivasi. Dengan adanya motivasi, maka belajar lebih keras, ulet, tekun dan memiliki konsentrasi penuh dalam proses belajar. Motivasi yang paling penting dalam dunia pendidikan adalah motivasi berprestasi ${ }^{1,2}$

Motivasi berprestasi diartikan sebagai keinginan dalam mencapai prestasi sebaik-baiknyaa, biasanya yang menjadi ukuran adalah diri sendiri (internal) ataupun orang lain (eksternal). Motivasi berprestasi merupakan dorongan atau sikap yang membangun untuk berbuat, menentukan arah dan menerima semangat untuk meraih prestasi belajar. ${ }^{3,4}$

Motivasi berprestasi inividu mengalami perubahan sesuai dengan usia individu tersebut dan sudah dapat dilihat sejak seseorang berusia lima tahun. Motivasi berprestasi berada dalam kondisi yang tinggi pada usia 20 sampai 30 tahun. Kebutuhan untuk berprestasi akan menurun pada saat middle age, ketika kebanyakan individu telah berada pada puncak karir. ${ }^{5}$

Komponen motivasi berprestasi yang membedakan individu dengan motivasi berprestasitinggi dan rendah, yaitu:individu yang memiliki motivasi berprestasi tinggi merasa bertanggung jawab atas tugas yang dikerjakannya dan tidak akan meninggalkan tugas itu sebelum berhasil menyelesaikannya, memilih tugas dengan taraf kesulitan sedang dan berani mengambil resiko bila mengalami kegagalan, cenderung kreatif dan tidak menyukai pekerjaan rutin, menyukai umpan balik karena memperhatikan kesalahan-kesalahan yang dilakukannya dan akan berusaha menyelesaikan setiap tugas dalam waktu secepat mungkin dan seefisien mungkin. ${ }^{6}$

Salah satu hal yang dapat mempengaruhi pembentukan motivasi berprestasi adalah lingkungan sosial. Seseorang yang mendapat dukungan dan diberikan kesempatan untuk mengembangkan diri di lingkungan sosialnya akan mempunyai motivasi yang lebih tinggi. ${ }^{7}$

Dukungan sosial didefinisikan sebagai adanya orang-orang yang memperhatikan, menghargai, dan mencintai. Dukungan sosial merupakan kenyamanan psikis dan emosional yang diberikan kepada individu oleh keluarga, teman, rekan, dan yang lainnya, dapat juga berupa pertukaran interpersonal dimana salah seorang memberikan bantuan atau pertolongan kepada yang lain. ${ }^{2,8}$

Dukungan sosial memiliki beberapa komponen-komponen, antara lain: dukungan emosional (Emosional Support), dukungan penghargaan (Esteem support), dukungan instrumental (Tangible or instrumental support), dukungan informasi (Informational support) dan dukungan jaringan sosial (network support). ${ }^{4}$

\section{METODE PENELITIAN}

Penelitian ini menggunakan metode penelitian deskriptif analitik dengan pendekatan cross sectional. Penelitian ini dilaksanakan di Fakultas Kedokteran Universitas Sam Ratulangi Manado pada bulan November 2014. Populasi dalam penelitian ini ialah seluruh mahasiswa angkatan 2013 Fakultas Kedokteran Universitas Sam Ratulangi sejumlah 259 mahasiswa. Besar sampel dalam penelitian ini ditentukan dengan menggunakan rumus slovin, sehingga besar sampel yang diperoleh 157 sampel.

Metode yang digunakan dalam penelitian ini adalah simpel random sampling. Penelitian ini menggunakan kuesioner dukungan sosial yang terdiridari 28 pertanyaan dan motivasi berprestasi yang terdiri dari 25 
pertanyaan,dengan pilihan jawaban menggunakan skor skala likert dan pilihan jawaban: sangat setuju, setuju, tidak setuju dan sangat tidak setuju.

Pengolan data dilakukan dengan cara: editing, coding, processing, cleaning. ${ }^{9}$ Analisis data dengan program komputer versi 21 dan menggunakan teknik analisis korelasi Spearman Rank.

\section{HASIL PENELITIAN}

Penelitian ini dilakukan di Fakultas Kedokteran Universitas Sam Ratulangi Manado pada bulan November 2014. Total populasi pada angkatan 2013 sebesar 259 mahasiswa, dan sampel dipilih dengan metode simpel random sampling.

\section{Analisi Univariat}

Analisis univariat pada penelitian ini bertujuan untuk mengetahui distribusi frekuensi mahasiswa angkatan 2013 Fakultas Kedokteran Universitas Sam Ratulangi.

Berdasarkan gambar 1 dilihat bahwa dari 157 responden jumlah responden usia 19 tahun merupakan kategori tertinggi sebesar 50,3\% dan usia 16 tahun merupakan kategori terendah sebesar $1,3 \%$.

Gambar 1. Distribusi berdasarkan usia responden

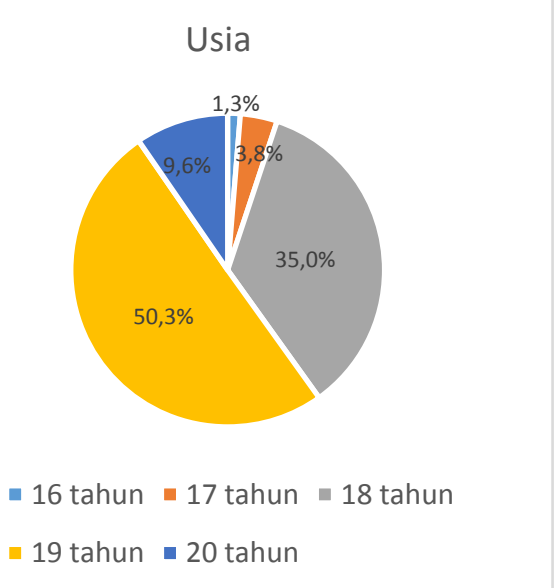

Berdasarkan gambar 2, proporsi responden perempuan lebih banyak dibandingkan dengan proporsi responden laki-laki. Proporsi responden perempuan sebesar 70,7\%, sedangkan proporsi responden laki-laki sebanyak 46 sebesar $29,3 \%$.

Gambar 2. Distribusi berdasarkan jenis kelamin responden

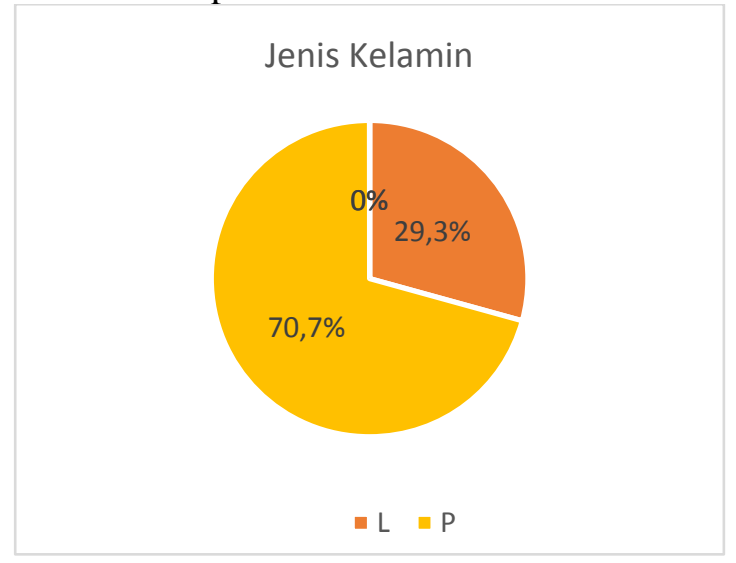

Berdasarkan gambar 3 dilihat bahwa, responden lebih banyak mendapatkan dukungan sosial rendah dibandingkan mendapatkan dukungan sosial tinggi. Dukungan sosial rendah sebesar 91,1\%, sedangkan dukungan sosial tinggi sebesar $8,9 \%$.

Gambar 3. Distribusi berdasarkan dukungan sosial responden

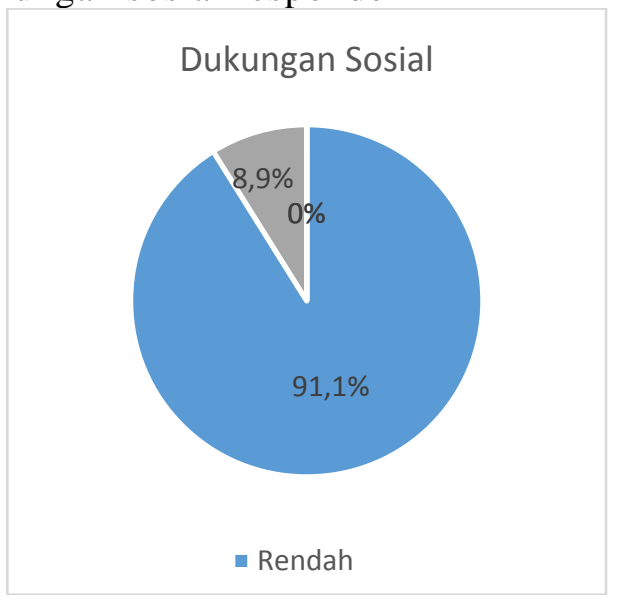

Berdasarkan gambar 4 dapat dilihat bahwa untuk motivasi berprestasi pada responden lebih banyak yang memiliki motivasi berprestasi rendah dibandingkan yang memiliki motivasi berprestasi tinggi. Motivasi berprestasi rendah sebesar $68,8 \%$ sedangkan motivasi berprestasi tinggi sebesar $31,2 \%$. 
Toding, David, Pali: Hubungan dukungan sosial ...

Gambar 4. Distribusi berdasarkan motivasi berprestasi responden

Motivasi Berprestasi

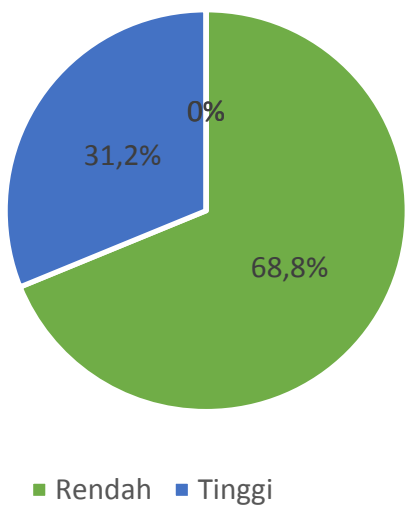

Berdasarkan gambar 4 dapat dilihat bahwa untuk motivasi berprestasi pada responden lebih banyak yang memiliki motivasi berprestasi rendah dibandingkan yang memiliki motivasi berprestasi tinggi. Motivasi berprestasi rendah sebesar $68,8 \%$ sedangkan motivasi berprestasi tinggi sebesar $31,2 \%$.

\section{Analisis Bivariat}

Analisis bivariat dimaksudkan untuk mengetahui hubungan antara variabel bebas dengan variabel terikat. Variabel bebas dalam penelitian ini adalah dukungan sosial dan variabel terikat motivasi berprestasi.

\begin{tabular}{|c|c|c|c|c|}
\hline & & & $\begin{array}{l}\text { Dukungan } \\
\text { Sosial }\end{array}$ & $\begin{array}{c}\text { Motivasi } \\
\text { Berprestasi }\end{array}$ \\
\hline \multirow{6}{*}{$\begin{array}{l}\text { Spearman's } \\
\text { rho }\end{array}$} & \multirow{3}{*}{$\begin{array}{l}\text { DUKUNGAN } \\
\text { SOSIAL }\end{array}$} & $\begin{array}{l}\text { Correlation } \\
\text { Coefficient }\end{array}$ & 1.000 & $.223^{* *}$ \\
\hline & & Sig. (2-tailed) & . & .005. \\
\hline & & $\mathrm{N}$ & 157 & 157 \\
\hline & \multirow{3}{*}{$\begin{array}{l}\text { MOTIVASI } \\
\text { BERPRESTASI }\end{array}$} & $\begin{array}{l}\text { Correlation } \\
\text { Coefficient }\end{array}$ & $.223^{* * 4}$ & 1.000 \\
\hline & & Sig. (2-tailed) & . 005. & . \\
\hline & & $\mathrm{N}$ & 157 & 157 \\
\hline
\end{tabular}

Pada tabel diatas dilihat bahwa diperoleh nilai koefisien korelasi sebesar 0,223 dengan taraf signifikansi 0,005 pada tingkat taraf kepercayaan $\alpha=0,05$ atau 95\%. Dari hasil perhitungan diperoleh nilai signifikansi sebesar $0,005<\alpha(0,05)$ maka hipotesis $\mathrm{h}_{1}$ diterima. Hasil tersebut menunjukkanbahwa terdapat hubungan positif dan signifikan antara dukungan sosial dengan motivasi berprestasi, dengan tingkat keeratan hubungan antara kedua variabel sebesar 0,223 yang termaksud dalam kategori rendah $(0,20$ 0,399).

\section{BAHASAN}

Berdasarkan hasil analisis Spearman Rank menunjukkan bahwa terdapat hubungan positif yang signifikan antara dukungan sosial dengan motivasi berprestasi pada mahasiswa angkatan 2013 Fakultas Kedokteran Universitas Sam Ratulangi. Hasil analisis tersebut menunjukkan nilai koefisien korelasi sebesar 0,223 yang termasuk dalam kategori rendah $(0,20-0,399)$ dengan nilai signifikansi 0,005 (sig< 0,05) dimana $\mathrm{h}_{1}$ diterima.

Dari hasil analisis Spearman Rank menunjukan tingkat keeratan hubungan (correlation coefficient) tergolong rendah. Hal ini dikarenakan subyek pada penelitian ini terbanyak usia 19 tahun yang masuk dalam kategori remaja akhir(usia 18 - 21 tahun), dimana motivasi berprestasi mulai meningkat dan berada dalam kondisi yang tinggi pada usia 20 sampai 30 tahun. $^{5}$

Remaja akhir sudah mengalami perubahan-perubahan dalam dirinya sehingga remaja sudah mulai memikirkan dirinya sendiri dan mulai mencari jati dirinya untuk melihat masa depannya, tanpa tergantung dengan sekelilingnya, dan sudah mulai terlihat bahwa mereka lebih memikirkan masa depan, mulai mempunyai pola berpikir sebagai peneliti, dimana mereka mampu membuat suatu perencanaan untuk mencapai suatu tujuan di masa depan. ${ }^{10,11}$

Pada remaja akhir bukan hanya dukungan sosial yang dapat mempengaruhi tinggi rendahnya motivasi berprestasi namun dipengaruhi juga oleh beberapa faktor internal seperti : usia, jenis kelamin, kemampuan, minat, harapan atau keyakinan. Hal ini sesuai dengan penelitian yang dilakukan oleh Rola F (2006) yang menyatakan bahwa 
konsep diri berhubungan dengan motivasi berprestasi pada remaja, apabila remaja merasa dirinya saat ini kurang berprestasi, namun dirinya merasa mampu untuk berprestasi maka remaja tersebutakan termotivasi untuk meningkatkan prestasinya. ${ }^{6,11}$

Pada penelitian inisebagian besar responden penelitian termasuk dalam kategori yang mendapat dukungan sosial rendah dibandingkan dengan yang mendapat dukungan sosial tinggi. Responden yang mendapat dukungan sosial rendah sebesar $91,1 \%$, sedangkan yang mendapat dukungan sosial tinggi sebesar $8,9 \%$.Motivasi berprestasi pada responden sebagian besar memiliki motivasi berprestasi rendah dibandingkan yang memiliki motivasi berprestasi tinggi. Motivasi berprestasi rendah sebesar $68,8 \%$, sedangkan motivasi berprestasi tinggi sebesar 31,2 \%.

Hasil penelitian ini sesuai dengan penelitian Sari PA (2006) yang mengatakan bahawa terdapat hubungan positif yang signifikan $(\mathrm{r}=0,759$; $\mathrm{p}=$ 0,000 ) antara dukungan sosial dan motivasi berprestasi, sementara itu, penelitian yang dilakukan diSMANegeri1Kajen pada siswa programRSBI oleh Yanuarini $\mathrm{H}$ dan Setyawan R (2010) juga membuktikan bahwa ada hubungan positif yang signifikan antara variabel dukungan sosial dengan variabel motivasi berprestasi pada siswa programRSBI diSMANegeri1Kajen. Dengan koefisien korelasirxy $=0,473$

dengantingkatsignifikansip $=0,000(p$ $<0,05)^{7,12}$

\section{SIMPULAN}

Berdasarkan hasil penelitian dapat disimpulkan bahwa terdapat hubungan positif yang signifikan antara dukungan sosial dengan motivasi berprestasi pada mahasiswa angkatan 2013 Fakultas Kedokteran Universitas Sam Ratulangi dengan nilai sig. $=0,005$ dengan demikian nilai sig. $<0,05$ yang artinya semakin tinggi dukungan sosial maka semakin tinggi motivasi berprestasi, sebaliknya semakin rendah dukungan sosial maka semakin rendah motivasi berprestasi.

\section{DAFTAR PUSTAKA}

1. Rambe AR. Korelasi Antara Dukungan Sosial Orang Tua dan Self-directed learning pada Siswa SMA. Jurnal Psikologi. 2010;37:216.

2. Mindo RR. Hubungan Antara

Dukungan Sosial Orang Tua dengan Prestasi Belajar Pada Anak Usia Sekolah Dasar. 2008. [cited 2014 Sep 22]. Available from: http://www.gunadarma.ac.id/library/a rticles/graduate/psychology/2008/Arti kel_10503225.pdf

3. Hartaji RD. Motivasi Berprestasi Pada Mahasiswa Yang Berkuliah Dengan Jurusan Pilihan Orang Tua. 2008. [cited 2014 Sep 18]. Available from: http://www.gunadarma.ac.id/library/ar ticles/graduate/psychology/2009/Artik el_10504208.pdf.

4. Rahmi VE. Pengaruh Dukungan Orang Tua dan Motivasi Belajar terhadap Prestasi Belajar Musik Pada Remaja. [Skripsi]. [Jakarta]: Fakultas Psikologi Univ Islam Negeri Syarif Hidayatullah;2011.[cited 2014 Sep 18]. Available from: http://repository.uinjkt.ac.id/dspace/bit stream/123456789/4926/1/EKA\%20V ERA\%20RAHMI-FPS.PDF

5. Garliah L, Nasution Sary KF. Peran Pola Asuh Orang Tua Dalam Motivasi Berprestasi. Jurnal Psikologia. 2005;1:38.

6. Sepfitri N. Pengaruh Dukungan Sosial Terhadap Motivasi Berprestrasi Siswa MAN 6. [ Skripsi ]. [ Jakarta ]: Fakultas Psikologi Univ Islam Negeri; 2011. [cited 2014 Sep 8]. Available from:

http://repository.uinjkt.ac.id/dspace/bit stream/123456789/4212/1/NETA\%20 SEPFITRI-FPS.PDF

7. Yanuarini H, Setyawan I, Ratri DD. Motivasi Berprestasi Ditinjau dari Dukungan Sosial dan Tingkat Pendidikan Orang Tua pada Siswa RSBI SMA Negeri 1 Kajen Kabupaten Pekalongan. 2010. [cited 2014 Sep 9]. Available from: http://ejournal- 
Toding, David, Pali: Hubungan dukungan sosial ...

s1.undip.ac.id/index.php/empati/articl e/download/5252/5057

8. Hikmah N. Hubungan Antara Dukungan Sosial Kawan Sebaya dengan Motivasi Berprestasi Alumni Siswa-siswi SMAN 38 Jakarta Lulusan Tahun 2011. [Skripsi]. [Jakarta]: Univ Indonesia; 2012. [cited 2014 Sep 11]. Available from: http://www.google.com/url?sa=t\&rct=j $\& \mathrm{q}=\&$ esrc $=$ s\& source $=$ web $\& \mathrm{~cd}=1 \& \mathrm{ve}$ $\mathrm{d}=0 \mathrm{CB} 0 \mathrm{QFjAA} \& \mathrm{url}=\mathrm{http} \% 3 \mathrm{~A} \% 2 \mathrm{~F} \%$ 2Flontar.ui.ac.id\%2Ffile\%3Ffile\%3Dd igital\%2F20281075-

Nurul\%2520Hikmah.pdf\&ei=tANfV M7YO8KwuASJu4KYDA\&usg=AFQ jCNHg6Id-

dHZ9R2ecs7mgGZcCF0kBiA\&sig2=f Uwhx3Q7em4e93hddXH-bA.

9. Kandou GD. Materi Kuliah Pengantar Pengolahan Data. Fakultas Kedokteran Univ Sam Ratulangi. Manado; 2014.
10. Sugiyanto. Pentingnya Motivasi Berprestasi dalam Mencapai Keberhasilan Akademik Siswa. 2011. [cited 2014 Jan 12]. Available from: http://staff.uny.ac.id/sites/default/files/ penelitian/sugiyanto-mpd/pentingnyamotivasi-berprestasi-dalam-mencapaikeberhasilan-akademik-siswa.pdf.

11. Rola F. Hubungan Konsep Diri dengan Motivasi Berprestasi pada Remaja. 2006. [cited 2014 Jan 13]. Available from:

http://repository.usu.ac.id/bitstream/12 3456789/1938/1/06010309.pdf

12. Sari PA. Hubungan Dukungan Sosial dengan Motivasi Berprestasi Siswa Sekolah Dasar. Psychology. 2006. [cited 2014 Jan 14].Available from: http://eprints.umm.ac.id/12415/1/H UBUNGAN_DUKUNGAN_SOSIA L_DENGAN_MOTIVASI_BERPR ESTASI_SISWA_SEKOLAH_DAS AR.pdf 
Jurnal e-Biomedik (eBm), Volume 3, Nomor 1, Januari-April 2015 